\title{
Penerapan Model Pembelajaran Kooperatif Tipe Snowball Throwing Untuk Meningkatkan Hasil Belajar Siswa Pada Mata Pelajaran Ips Kelas V Sdn Mapala Kota Makassar
}

\author{
Nurhaedah A dan Muhammad Amran \\ Universitas Negeri Makassar \\ email: nurhaedah@yahoo.co.id)
}

\begin{abstract}
Abstrak. Penelitian ini bertujuan untuk untuk mengetahui Penerapan Model Pembelajaran Kooperatif Tipe Snowball Throwing dalam Meningkatkan Hasil Belajar Siswa Pada Mata Pelajaran IPS Di Kelas V SDN Mappala Kota Makassar, Pendekatan yang digunakan dalam penelitian ini adalah kualitatif deskriptif dengan jenis penelitian ini adalah Penelitian Tindakan Kelas (PTK) yang bersiklus yaitu meliputi perencanaan, pelaksanaan, observasi, dan refleksil. Populasi penelitian adalah Siswa kelas V SD Mappala Kecamatan Rappocini, Kota Makassar berjumlah 20 orang . Teknik pengumpulan data penelitian ini adalah dengan tes, wawancara langsung, pengamatan dan catatan lapangan. Analisis data menggunakan teknik statistik deskriptif untuk mendeskripsikan hasil belajar siswa. Hasil penelitian adalah sebagai berikut; (1) dengan menggunakan pendekatan Kooperatif Tipe Snowball Trawing pada siswa kelas V SD Mappala dapat meningkatkan hasil belajar siswa pada mata pelajaran IPS, (2) siswa sudah aktif dalam pembelajaran pendekatan Kooperatif Tipe Snowball Trawing, (3) guru mampu melaksanakan pembelajaran pendekatan Kooperatif Tipe Snowball Trawing. adanya peningkatan hasil belajar siswa dengan menggunakan pendekatan Kooperatif Tipe Snowball Trawing karena siswa pada saat belajar siswa lebih aktif dalam pelaksanaan proses pembelajaran.
\end{abstract}

Kata Kunci : Hasil Belajar, Pendekatan Kooperatif Tipe Snowball Trawing

\begin{abstract}
This research aimed to determine the Application of Cooperative Learning type Snowball Throwing in Improving Learning Outcomes At Subjects IPS In Class V Elementary School Mappala of Makassar, the approach used in this study is a qualitative descriptive type of research is the Classroom action research cyclical which includes planning, implementation, observation, and refleksi. The study population were students of class V Elementary School Mappala Rappocini Subdistrict, City of Makassar numbered 20 people. Data collection techniques of this research is to test, interviews, observations and field notes. Analysis data using descriptive statistical techniques to describe the results of student learning. The results of the study are as follows; (1) by using an approach Cooperative mode Snowball Trawing in Class V Elementary School Mappala can improve student learning outcomes in social studies, (2) the student is already active in the learning approach Cooperative type Snowball Trawing, (3) the teacher is able to carry out learning approach Cooperative tipe Snowball Trawing. an increase in student learning outcomes using a cooperative approach Trawing Snowball type because students on student learning is more active in the implementation of the learning process.
\end{abstract}

Keyword: Learning Outcomes, Approach Cooperative Type Snowball Trawing 


\section{PENDAHULUAN}

Mata pelajaran IPS disekolah dasar merupakan perwujudan dari satu pendekatan interdisipliner dari pelajaran ilmu-ilmu sosial. IPS mengkaji seperangkat peristiwa, konsep dan generalisasi yang berkaitan dengan isu sosial. Melalui mata pelajaran IPS, siswa diarahkan untuk dapat menjadi warga Negara Indonesia yang demokratis, dan bertanggung jawab, serta warga dunia yang cinta damai. Mata pelajaran IPS dirancang untuk mengembangkan kemampuan siswa agar menjadi anggota masyarakat yang memiliki pengetahuan, pemahaman, dan kemampuan analisis terhadap kondisi sosial masyarakat dalam memasuki kehidupan bermasyarakat yang dinamis. Ilmu pengetahuan sosial (IPS) sebagai bidang studi yang mengandung nilai-nilai moral, kesejarahan, dan kemasyarakatan perlu diperkenalkan dan diajarkan sejak dini kepada siswa. Hal ini dikarenakan bidang studi IPS sebagai salah satu bidang studi di sekolah yang memegang peranan penting dalam menanamkan nilai-nilai kesetiakawanan sosial, semangat kebangsaan, dan cinta tanah air melalui pemahaman terhadap sejarah perjuangan bangsa dan nilai-nilai luhur dalam hidup bermasyarakat sebagai makhluk individu dan makhluk sosial.

Berdasarkan uraian tersebut, maka upaya peningkatan kualitas hasil belajar mengajar dalam pendidikan IPS merupakan suatu kebutuhan yang sangat mendesak untuk dilakukan. Salah satu model pembelajaran yang dapat meningkatkan hasil belajar siswa adalah penerapan Cooperative Learning tipe Snowball Throwing. Model pembelajaran kooperatif tipe Snowball Throwing merupakan pengembangan dari model pembelajaran diskusi dan merupakan bagian dari model pembelajaran kooperatif (Shoimin, 2014). Pada model ini kegiatan belajar diatur dan ditata dengan rapi sesuai dengan langkah yang ditentukan sehingga proses belajar mengajar dapat berlangsung dengan baik dan lebih menyenangkan. Snowball Throwing dapat diartikan melempar bola salju. Metode pembelajaran ini melatih siswa untuk lebih tanggap menerima pesan dari siswa lain dalam bentuk bola salju yang terbuat dari kertas, dan menyampaikan pesan tersebut kepada temannya dalam satu kelompok.

Telah banyak penelitian terdahulu tentang penerapan dmodel pembelajaran kooperatif tipe Snowball Throwing dalam meningkatkan hasil belajar siswa di antaranya penelitian dari Vera Daniati (2013) hasil penelitian menunjukkan bahwa hasil belajar siswa meningkat setelah menerapkan model pembelajaran kooperatif tipe Snowball Throwing. Hasil serupa pun ditemukan dari penelitian Yuni (2011) bahwa penerapan model pembelajaran kooperatif tipe Snowball Throwing dapat meningkatkan hasil belajar siswa dalam pembelajaran IPS.

Sehubungan hal tersebut peneliti terinspirasi untuk membahas dalam suatu penelitian tentang Penerapan model pembelajaran kooperatif tipe Snowball Throwing Untuk Meningkatkan Hasil Belajar Siswa Pada Mata Pelajaran IPS Di Kelas V SDN Mapala Kota Makassar

\section{Pembelajaran Kooperatif Tipe Snowball Throwing.}

Pembelajaran Kooperatif muncul dari konsep bahwa siswa akan lebih mudah menemukan dan memahami konsep yang sulit jika mereka saling berdiskusi dengan temannya. Di dalam kelas kooperatif siswa belajar bersama dalam kelompok-kelompok kecil yang terdiri dari 4-5 0rang siswa yang sederajat tetapi heterogen, kemampuan, jenis kelamin, suku/ras, dan satu sama lain saling membantu. Tujuan dibentuknya kelompok tersebut adalah untuk memberikan kesempatan kepada semua siswa untuk dapat terlibat secara aktif dalam proses berfikir dan kegiatan belajar. Selama bekerja dalam kelompok, tugas anggota kelompok adalah mencapai ketuntasan materi yang disajikan oleh guru, dan saling membantu teman sekelompoknya untuk mencapai ketuntasan belajar.

Roger dkk (Huda, 2011: 29) menyatakan bahwa:

pembelajaran kooperatif merupakan aktivitas pembelajaran kelompok yang diorganisir oleh salah satu prinsip bahwa pembelajaran harus didasarkan pada perubahan informasi secara sosial diantara kelompok-kelompok pembelajaran yang di dalamnya setiap 
pembelajar bertanggung jawab atas pembelajarannya sendiri dan didorong untuk meningkatkan pembelajaran anggota-anggota yang lain.

Sedangkan menurut Artz dan Newman (Huda, 2011: 32) mendefinisikan pembelajaran kooperatif sebagai: kelompok kecil pembelajar/ siswa yang bekerja saama dalam satu tim untuk mengatasi suatu masalah, menyelesaikan sebuah tugas, atau mencapai suatu tujuan bersama".

Secara singkat pembelajaran kooperatif mengacu pada metode pembelajaran dimana siswa bekerja sama dalam belajar.

\section{a. Model pembelajaran kooperatif tipe Snowball Throwing}

Model pembelajaran kooperatif tipe Snowball Throwing merupakan pengembangan dari model pembelajaran diskusi dan merupakan bagian dari model pembelajaran kooperatif. Hanya saja, pada model ini kegiatan belajar diatur sedemikian rupa sehingga proses belajar mengajar dapat berlangsung dengan lebih menyenangkan.

Berdasarkan Shoimin (2014: 174) mengatakan bahwa :

Dengan penerapan model ini, diskusi kelompok dan interaksi antar siswa dari kelompok yang berbeda memungkinkan terjadinya saling sharing pengetahuan dan pengalaman dalam upaya menyelesaikan permasalahan yang mungkin timbul dalam diskusi yang berlangsung secara lebih interaktif dan menyenangkan.

Selanjutnya Shoimin mengatakan salah satu permasalahan serius yang sering terjadi dalam proses belajar adalah adanya perasaan ragu pada diri siswa untuk menyampaikan permasalahan yang dialaminya dalam memahami materi pelajaran. Guru sering mengalami kesulitan dalam menangani masalah ini. Tapi, melalui penerapan model pembelajaran kooperatif tipe Snowball Throwing ini, siswa dapat menyampaikan pertanyaan atau permasalahannya dalam bentuk tertulis yang nantinya akan didiskusikan bersama. Dengan demikian, siswa dapat mengungkapkan kesulitan-kesulitan yang dialaminya dalam memahami materi pelajaran.

Aqib (2014: 27) mengemukakan langkah-langkah model pembelajaran kooperatif tipe Snowball Throwing sebagai berikut :

1) Guru menjelaskan secara singkat materi yang akan dibahas

2) Guru membagi siswa kedalam 4 kelompok dengan masing-masing kelompok beranggotakan 5 orang.

3) Kemudian tiap-tiap ketua kelompok mendapatkan penjelasan dari guru yang kemudian diteruskan kepada anggota kelompoknya.

4) Setelah semua siswa mengetahui materi pembelajaran setiap siswa menuliskan satu pertanyaan yang tidak diketahuinya kedalam selembar kertas lalu kertas tersebut diremas menyerupai bola.

5) Selanjutnya masing-masing siswa memiliki satu bola pertanyaan.

6) Guru membimbing siswa untuk membagi bola pertanyaan tersebut kepada teman-temanya. Hendaknya pembagian bola pertannyaan dilakukan secara berkelompok

7) Setelah semua siswa mendapatkan bola pertanyaan dari temanya, secara bergiliran membuka bola tersebut lalu menjawab pertanyaan yang terdapat dalam bola tersebut.

8) Sementara temannya menjawab pertanyaan, siswa yang lain mengevaluasi kebenaran jawaban dari temannya dan dapat menanggapi jawaban temannya

9) Setelah semua bola pertanyaan terjawab. Guru memberikan penguatan materi

10) Guru membagikan LKS kepada siswa

11) Guru memberi penghargaan atas hasil kerja siswa secara individu maupun kelompok

Berdasarkan pemaparan tersebut dapat disimpulkan bahwa model pembelajaran kooperatif tipe Snowball Trhowing adalah model pembelajaran yang mengaktifkan siswa secara keseluruhan karena pelajaran dibuat seperti permainan sehingga siswa lebih aktif dan 
JIKAP PGSD: Jurnal Ilmiah Ilmu Kependidikan

menyenangkan dalam proses belajar

mengajar.

\section{Hasil Belajar}

Belajar merupakan suatu peristiwa dan tindakan sehari-hari. Dari sisi siswa sebagai pelaku belajar dan dari sisi guru sebagai pembelajar. Proses belajar terjadi melalui banyak cara baik disengaja maupun tidak disengaja dan berlangsung seumur hidup yang menuju pada suatu perubahan pada diri pembelajaran.

Seperti yang dikemukakan oleh Hilgard dan Bowel (Fathurrohman, 2007: 5), bahwa: Belajar berhubungan dengan perubahan tingkah laku seseorang terhadap sesuatu situasi tertentu yang disebabkan oleh pengalamannya yang berulang-ulang dalam situasi itu, dimana perubahan tingkah laku itu tidak dapat dijelaskan atau dasar kecenderungan respon pembawaan, kematangan atau keadaan-keadaan sesaat seorang (misalnya kelelahan, pengaruh obat dan sebagainya).

Berkaitan dengan kedua pendapat para ahli diatas, Gagne ( Dimyati, 2010:10 ) merumuskan bahwa " belajar merupakan kegiatan yang kompleks. Hasil belajar merupakan kapabilitas. Setelah belajar orang memiliki keterampilan, pengetahuan, sikap, dan nilai. Timbulnya kapabilitas tersebut adalah dari simulasi yang berasal dari lingkungan dan proses kognitif yang dilakukan oleh pebelajar".

Jadi, belajar adalah suatu proses untk mencapai suatu tujuan atau merupak langkahlangkah atau prosedur yang harus ditempuh oleh suatu individu untuk memperoleh suatu perubahan tingkah laku yang baru secara keseluruhan, sebagai hasil pengalaman individu itu sendiri di dalam interaksi dengan lingkungannya dan hasilnya bersifat permanen.

\section{Hasil Belajar}

Dalam proses belajar, banyak segi yang sepatutnya didicapai sebagai hasil belajar, yaitu meliputi pengetahuan dan pemahaman tentang konsep, kemampuan menerapkan konsep, kemampuan menjabarkan dan menarik kesimpulan serta menilai kemanfaatan suatu konsep, menyenangi dan memberikan respon yang positif terhadap sesuatu yang dipelajari dan diperoleh kecakapan melakukan suatu kegiatan tertentu. Siswa mengalami suatu proses belajar. Dalam proses belajar tersebut, siswa menggunakan kemampuan mentalnya untuk mempelajari bahan belajar. Kemampuankemampuan kognitif, afektif, psikomotorik yang dibelajarkan dengan bahan belajar menjadi semakin rinci dan menguat. Adanya informasi tentang sasaran belajar, adanya penguatanpenguatan, adanya evaluasi dan keberhasilan belajar menyebabkan siswa semakin sadar akan kemampuan dirinya. Hal ini akan memperkuat keinginan untuk semakin mandiri.

Menurut Bloom dkk (Dimyati, 2009), ada tiga ranah (dominan) hasil belajar, yaitu:

1. Ranah kognitif, merupakan aspek yang berkaitan dengan kemampuan berpikir, kemampuan memperoleh pengetahuan, kemampuan yang berkaitan dengan perolehan pengetahuan, pengenalan, pemahaman, konseptualisasi, penetuan dan penalaran;

2. Ranah afektif, merupakan aspek yang berkaitan dengan perasaan, emosi, sikap, derajat penerimaan, atau penolakan terhadap suatu obyek;

3. Ranah psikomotorik, merupakan aspek yang berkaitan dengan kemampuan melakukan pekerjaan yang melibatkan anggota badan, kemampuan yang berkaitan dengan gerak fisik.

Pemahaman dan struktur kognitif dapat diperoleh seseorang melalui pengalaman dan melakukan suatu kegiatan. Dalam khazanah peristilahan pendidikan, hal ini dikenal dengan "learning by doing yaitu belajar dengan melakukan suatu kegiatan". Pemahaman itu sendiri bersifat abstrak. Sesuatu yang abstrak akan mudah diperoleh dengan jalan melakukan kegiatan-kegiatan yang nyata atau kogkrit, sehingga orang yang bersangkutan memperoleh pengalaman yang menuntun pada pemahaman yang bersifat abstrak. Hasil belajar yakni perstasi yang dicapai oleh siswa setelah mengikuti proses belajar mengajar yang berkenaan dengan materi suaru mata pelajaran yang mencakup tiga ranah, yaitu kognitif, afektif, dan psikomotorik. Hasil belajar tersebut dapat diukur dengan menggunakan instrumen hasil belajar.

Hasil belajar juga dapat diartikan sebagai suatu hasil yang dicapai seseorang yang ditandai dengan adanya perubahan pada diri orang tersebut. Hasil belajar dapat diukur secara langsung dengan menggunakan tes.hasil belajar dapat dilihat dari hasil nilai Ulangan Harian (formatif), nilai Ulangan Tengah Semester (UTS), dan nilai ulangan semester (Sumatif) 


\section{METODE}

Penelitian ini dikategorikan sebagai penelitian tindakan kelas. Penelitian dilaksanakan untuk memperoleh informasi yang akurat tentang pelaksanaan pembelajaran dengan menggunakan Pembelajaran kontekstual sehingga dapat diketahui kekurangan dan kelebihan setiap komponennya.

Subjek penelitian ini adalah siswa SD kelas V SD Negeri Mappala Kota Makassar. Teknik pengumpulan data yang digunakan dalam penelitian ini adalah pengambilan data dengan observasi, wawancara, tes hasil belajar siswa dan catatan lapangan. Teknik pembuatan soal yang dilakukan dengan menggunakan daftar pertanyaan yang telah disusun, digunakan untuk mengumpulkan data mengenai semua komponen penelitian dan dilengkapi dengan kegiatan observasi yang dilakukan oleh peneliti mengenai kondisi pembelajaran IPS di sekolah tersebut yang menjadi tempat pelaksanaan penelitian. .

Dalam penelitian ini, peneliti terlebih dahulu melaksanakan tes awal berupa diagnostik untuk mengetahui kemampuan awal siswa sebelum diberikan tindakan disamping observasi. Observasi awal untuk dapat mengetahui ketepatan tindakan yang akan diberikan dalam rangka meningkatkan hasil belajar IPS.

Berdasarkan hasil evaluasi dan observasi awal, maka dalam refleksi ditetapkan tindakan yang digunakan untuk meningkatkan hasil belajar IPS yaitu melalui pembelajaran dengan menggunakan keterampilan proses IPS.

Kriteria yang digunakan untuk mengungkapkan kemampuan siswa adalah sesuai dengan kriteria standar yang diungkapkan Nurkancana ( 1986: 39) sebagai berikut : (Tingkat penguasaan 90\% - 100\% dikategorikan sangat tinggi. $80 \%-89 \%$ dikategorikan tinggi. $65 \%-79 \%$ dikategorikan sedang. 55\% - 64\% dikategorikan rendah, dan 0\% - 54\% dikategorikan sangat rendah). Berdasarkan kriteria standar tersebut, maka peneliti menentukan tingkat kriteria keberhasilan tindakan pada penelitian ini dilihat dari kemampuan siswa memahami materi daur air secara klasikal pada setiap siklus telah meningkat dan menunjukan tingkat pencapaian $70 \%$

Penelitian ini adalah Penelitian Tindakan Kelas (PTK). Kemmis dan Taggart yang menyatakan bahwa Proses penelitian dalam tindakan merupakan sebuah siklus atau proses daur ulang yang terdiri dari empat aspek fundamental. Diawali dari aspek mengembangkan perencanaan kemudian melakukan tindakan sesuai dengan rencana, observasi/pengamatan terhadap tindakan, dan diakhiri dengan melakukan refleksi. Kegiatan penelitian ditempuh dalam suatu tahapan sehingga pemahaman siswa tentang daur air dapat tercapai dengan baik.

ada beberapa faktor yang menjadi fokus dalam penelitian ini, yaitu sebagai berikut:

1. Penerapan model pembelajaran Snowball Throwing merupakan kegiatan pembelajaran IPS di kelas V SDN Mapala Kota Makassar.

2. Hasil belajar IPS merupakan nilai hasil tes setiap siklus dalam bentuk tes tertulis.

Penelitian ini dilaksanakan di SDN Mapala Kota Makassar dalam bidang studi Ilmu Pengetahuan Sosial (IPS), dan waktu pelaksanaan tindakannya adalah pada semester genap tahun ajaran 2015/2016. Pemilihan SDN Mapala Kota Makassar sebagai tempat penelitian, dilatar belakangi oleh pertimbangan sebagai berikut :

a. Sarana dan prasarana sekolah cukup memadai untuk dijadikan tempat penelitian

b. Rendahnya hasil belajar IPS yang dialami siswa kelas V SDN Mapala Kota Makassar dalam pelajaran Ilmu Pengetahuan Sosial (IPS)

c. Kepala sekolah dan guru-guru di SDN Mapala Kota Makassar dapat menjadi pihak yang siap bekerja sama dalam terlaksananya penelitian

Penelitian tindakan kelas ini, dilaksanakan sebanyak dua siklus dimana setiap siklus dilaksanakan dua kali pertemuan dan setiap pertemuan menggunakan alokasi waktu 2 x 35 menit. Model penelitian tindakan kelas berbentuk siklus yang meliputi : Perencanaan, pelaksanaan, pengamatan, dan refleksi

Untuk mengetahui keefektifan suatu metode dalam kegiatan pembelajaran, perlu dilakukan analisis data. Akib (2014) bahwa Pada PTK ini digunakan analisis deskriptif kualitatif yaitu suatu metode penelitian yang bersifat menggambarkan kenyataan atau fakta sesuai dengan data yang diperoleh dengan tujuan untuk mengetahui hasil belajar yang dicapai siswa juga untuk mengetahui respon siswa terhadap kegiatan pembelajaran serta aktivitas siswa selama proses pembelajaran berlangsung. 
JIKAP PGSD: Jurnal Ilmiah Ilmu Kependidikan

Sedangkan menurut Sugiyono (2011: 338) ada 3 tahapan dalam menganalisis data yaitu :
Mereduksi data, menyajikan data, menarik kesimpulan dan verifikasi.

Tabel 3.1. Tingkat Penguasaan Materi

\begin{tabular}{ccc}
\hline No & Interval & Kategori Hasil Belajar \\
\hline 1 & $0-39,9$ & Sangat Kurang \\
\hline 2 & $40,0-54,9$ & kurang \\
\hline 3 & $55,0-69,9$ & Cukup \\
\hline 4 & $70,0-84,5$ & Baik \\
\hline 5 & $85,0-100$ & Sangat Baik \\
\hline
\end{tabular}

Indikator keberhasilan dalam penelitian tindakan ini meliputi indikator proses yang diperoleh melalui observasi yang dilaksanakan oleh peneliti untuk mengamati atau melihat langsung kegiatan yang dilakukan guru dan siswa dalam mengikuti proses pembelajaran dan indikator hasil yaitu semua langkah-langkah pembelajaran terlaksana dengan kategori baik. Proses pembelajaran dikatakan berhasil apabila mencapai batas minimal $75 \%$ pelaksanaannya telah sesuai dengan skenario pembelajaran. Sedangkan hasil belajar siswa dikategorikan berhasil apabila terdapat $75 \%$ dari jumlah siswa yang memperoleh nilai $\geq 65$ pada mata pelajaran IPS melalui model pembelajaran kooperatif tipe Snowball Throwing maka kelas dianggap tuntas secara klasikal.

\section{HASIL PENELITIAN}

Sebelum melaksanakan tindakan penelitian, peneliti melakukan kunjungan pada sekolah yang akan dijadikan lokasi penelitian. Tujuan dari kunjungan tersebut adalah untuk melakukan koordinasi dengan kepala sekolah agar diizinkan melaksanakan penelitian pada sekolah yang dipimpinnya. Dari hasil koordinasi tersebut peneliti diizinkan untuk melaksanakan penelitian pada sekolah yang bersangkutan. Selanjutnya kepala sekolah menyerahkan sepenuhnya pada guru kelas $\mathrm{V}$ untuk membicarakan rencana selanjutnya.

Berdasarkan hasil koordinasi guru kelas dan kepala sekolah, maka ditetapkan bahwa kelas V pada SDN Mappala Kota Makassar yang dijadikan tempat sumber data penelitian. Peneliti selanjutnya berkomunikasi dengan guru kelas untuk meminta kesediaannya membantu dalam pelaksanaan penelitian. Hal ini sebagai upaya meningkatkan kemampuan belajar siswa, dimana peneliti bertindak sebagai guru dan guru kelas sebagai observer.
Hasil penelitian dideskripsikan ke dalam uraian tahapan berupa siklus-siklus pembelajaran yang dilakukan. Dalam penelitian ini pembelajaran di laksanakan dengan dua siklus, yaitu sebagai berikut.

\section{Hasil Penelitian Siklus I}

a. Perencanaan

Rumusan hasil perencanaan pada siklus 1 yang terdiri atas dua kali pertemuan adalah sebagai berikut:

1) Menyamakan persepsi antara peneliti dengan guru kelas $\mathrm{V}$ tentang materi yang diajarkan.

2) Mengkonsultasikan dengan guru kelas V Rancangan Pelaksanaan Pembelajaran (RPP), Lembar Kegiatan Siswa (LKS) berdasarkan KTSP, Tes Formatif di akhir siklus.

3) Membuat lembar observasi aktifitas guru dan siswa yang telah disusun dan dikembangkan.

\section{b. Pelaksanaan}

Pelaksanaan pembelajaran pada mata pelajaran IPS melalui model pembelajaran kooperatif tipe Snowball Throwing di kelas V SDN Mappala Kota Makassar untuk siklus I dilaksanakan 2 kali pertemuan. Pertemuan ke-1 yang dilaksanakan pada hari rabu, 7 September 2016 pukul 08.00-09.15 WITA, pertemuan ke 2 dilaksanakan pada hari hari jumat, 9 september 2016 pukul 07.30-09.00 WITA. Pelaksanaan pembelajaran pada 2 kali pertemuan ini, diikuti oleh semua siswa kelas V SDN Mappala sebanyak 20 orang dengan siswa laki-laki 8 dan 12 orang siswa perempuan.

\section{c. Observasi dan Hasil Belajar Siswa}

Setiap siklus diamati selama proses pelaksanaan tindakan dan setelah tindakan. Adapun hasil dari observasi yang diamati selama proses pelaksanaan tindakan yaitu aktivitas guru dan aktivitas siswa serta hasil belajar setelah proses pelaksanaan tindakan.

\section{a) Aspek Siswa}

Lembar observasi kegiatan belajar siswa digunakan untuk mengetahui keaktifan belajar 
siswa dalam proses pembelajaran IPS dengan menggunakan model pembelajaran kooperatif tipe Snowball Throwing. Pada setiap pertemuan, observer mengamati dan memperhatikan belajar siswa di dalam proses pembelajaran, kemudian mengisi lembar observasi berdasarkan lembar observasi siswa yang diisi oleh guru kelas (observer).

\section{2) Hasil Observasi Siklus I Pertemuan II a) Aspek Guru}

Berdasarkan lembar observasi guru yang diisi oleh guru kelas (observer), dari hasil mengajar guru pada pertemuan pertama dianggap masih belum berhasil sehingga dilaksanakan kembali pada pertemuan kedua.

\section{b) Aspek Siswa}

Lembar observasi kegiatan belajar siswa digunakan untuk mengetahui keaktifan belajar siswa dalam proses pembelajaran pada petemuan pertama tapi dianggap belum berhasil sehingga dilakukan kembali pada pertemuan kedua.

\section{d. Hasil Belajar Siswa}

Pengukuran hasil belajar siswa pada mata pelajaran IPS di kelas V SDN Mappala Kota Makassar, diklasifikasikan yaitu: baik sekali, baik, cukup, kurang, dan sangat kurang.

Berdasarkan hasil tes penelitian dijelaskan bahwa dari 20 subjek penelitian, terdapat 6 siswa atau $30 \%$ yang memiliki hasil belajar pada kategori kurang, disusul kategori cukup sebanyak 10 siswa atau 50\%, dan kategori baik sebanyak 4 siswa atau $20 \%$. Sesuai dengan nilai rata-rata hasil belajar siswa pada mata pelajaran IPS pada siklus pertama sebesar $62,01 \%$ dimana nilai rata-rata tersebut berada pada inteval 60,0 - 80,0 yang berarti cukup. Jadi, hasil belajar siswa pada mata pelajaran IPS dikelas V SDN Mappala Kota Makassar pada tes pertama dalam kategori cukup, walaupun terdapat pula $30 \%$ siswa yang memiliki hasil belajar pada kategori kurang. Bahkan terdapat $60 \%$ siswa yang tidak tuntas belajarnya sesuai standar KKM 70.

\section{e. Refleksi}

Dari segi proses pembelajaran yang telah dilakukan dengan mengacu pada hasil observasi maka dapat disimpulkan :

Siklus I pertemuan I. Untuk kegiatan guru indikator penilaiannya yakni keterlaksanaan deskriptor dan instruksi jelas dan mudah dipahami. Nilai yang didapatkan untuk kegiatan mengajar guru pada pertemuan pertama siklus I adalah 57,14\%. Untuk kegiatan siswa indikator penilaiannya adalah keaktifan dan keterlaksanaan deskriptor. Nilai yang didapatkan untuk kegiatan siswa pada pertemuan pertama siklus I adalah $60 \%$. Jadi rata-rata nilai yang didapatkan dari kegiatan guru dan kegiatan siswa adalah 58,57\% belum memenuhi standar keberhasilan dari segi proses yakni $\geq 75 \%$. Hasil observasi selama pelaksanaan tindakan pertemuan pertama siklus I dianalisis, kemudian didiskusikan oleh peneliti yang bertindak sebagai guru dengan guru kelas sebagai observer yang kemudian kekurangan pada pertemuan pertama akan diperbaiki di pertemuan II siklus I.

Pada siklus I pertemuan II. Untuk kegiatan guru indikator penilaiannya yakni keterlaksanaan deskriptor dan instruksi jelas dan mudah dipahami, Nilai yang didapatkan untuk kegiatan mengajar guru pada pertemuan ke dua siklus I adalah $71,42 \%$. Sedangkan untuk kegiatan siswa indikator penilaiannya adalah keaktifan dan keterlaksanaan deskriptor. Nilai yang didapatkan untuk kegiatan siswa pada pertemuan ke dua siklus I adalah 73,33\%. Jadi rata-rata nilai yang didapatkan dari kegiatan guru dan kegiatan siswa adalah $72,36 \%$ belum memenuhi standar keberhasilan dari segi proses yakni $\geq 75 \%$.

Dari segi hasil pembelajaran. Hasil belajar siswa rata-rata 62,01 di mana nilai ratarata tersebut belum memenuhi standar KKM yaitu 65 , bahkan terdapat $46,67 \%$ siswa yang memiliki hasil belajar pada kategori kurang, dan $60 \%$ yang tidak tuntas belajarnya secara klasikal. Hal ini menunjukkan bahwa pada siklus I ketuntasan secara klasikal belum mencapai $75 \%$ siswa yang memperoleh nilai $\geq$ 65.

Disimpulkan bahwa penelitian yang dilakukan pada siklus I dari segi proses dan hasil belajar belum dikategorikan berhasil. Atas dasar ini peneliti melanjutkan penelitiannya ke siklus berikutnya yakni siklus II.

\section{Hasil Penelitian Siklus II}

Siklus ke dua di laksanakan sebanyak dua kali pertemuan, dan kegiatan siklus II merupakan pengulangan dari siklus I. Kegiatan yang dilakukan pada tindakan siklus II meliputi perencanaan, pelaksanaan, observasi dan refleksi. Masing-masing kegiatan diuraikan sebagai berikut:

\section{a. Perencanaan}

Langkah-langkah yang dilakukan dalam siklus II ini pada umumnya merupakan hasil refleksi pada siklus I, dengan beberapa evaluasi, 
dan perbaikan sesuai dengan kenyataan di lapangan. Adapun kegiatan perencanaan sebagai berikut:

1) Peneliti berdiskusi dengan guru kelas tentang hal-hal yang perlu dipersiapkan pada tindakan berikutnya demi mendapatkan hasil yang lebih baik dari yang sebelumnya.

2) Peneliti menyusun dan merencanakan kegiatan pembelajaran (RPP), Lembar Kerja Siswa, Tes formatif diakhir siklus serta format observasi guru dan siswa sesuai langkah-langkah model pembelajaran kooperatif tipe Snowball Throwing.

3) Peneliti mengkonsultasikan RPP, LKS, Tes Formatif dan format observasi dengan guru kelas.

4) Peneliti dan guru merencanakan langkahlangkah antisipatif terhadap penyebabpenyebab ketidak berhasilan pada tindakan siklus I.

\section{b. Pelaksanaan}

Pelaksanaan pembelajaran pada mata pelajaran IPS melalui model pembelajaran kooperatif tipe Snowball Throwing di kelas V SDN Mappala untuk siklus II dilaksanakan 2 kali pertemuan. Pertemuan I yang dilaksanakan pada hari rabu 21september pukul 07.30-09.00 WITA, pertemuan II dilaksanakan pada hari jumat 3 September 2016 pukul 07.30-09.00 WITA. Pelaksanaan pembelajaran pada 2 kali pertemuan ini, diikuti oleh semua siswa kelas $\mathrm{V}$ SDN mappala sebanyak 20 orang dengan siswa laki-laki 12 dan 8 orang siswa perempuan.

\section{Pelaksanaan Siklus II Pertemuan I}

Proses pembelajaran IPS melalui pembelajaran kooperatif tipe Snowball Trowing, dibagi menjadi tiga kegiatan, yaitu: (a) kegiatan awal, (b) kegiatan inti, dan (c) kegiatan akhir.

\section{Pelaksanaan Siklus II Pertemuan II}

Setelah siklus II pertemuan I selesai dilaksanakan, penelitian dilanjutkan pada siklus II pertemuan II dengan langkah - langkah pembelajaran yang sama seperti pada pertemuan I, hanya saja dengan materi yang berbeda. Adapun kegiatannya sebagai berikut:

Proses pembelajaran pada siklus II pertemuan II mata pelajaran IPS melalui pembelajaran kooperatif tipe Snowball Throwing, dibagi menjadi tiga kegiatan, yaitu: (a) kegiatan awal, (b) kegiatan inti, dan (c) kegiatan akhir.

\section{c. Observasi dan Hasil Belajar Siswa}

Setiap siklus diamati selama proses pelaksanaan tindakan dan setelah tindakan. Adapun hasil dari observasi yang diamati selama proses pelaksanaan tindakan yaitu aktivitas guru dan aktivitas siswa serta hasil belajar setelah proses pelaksanaan tindakan.

\section{Hasil Observasi Siklus II Pertemuan I}

\section{a. Aspek Guru}

Lembar observasi kegiatan mengajar guru digunakan untuk mengetahui keaktifan mengajar guru dalam proses pembelajaran IPS dengan menggunakan model pembelajaran kooperatif tipe Snowball Throwing. Pada setiap pertemuan, observer mengamati dan memperhatikan guru di dalam proses pembelajaran, kemudian mengisi lembar observasi berdasarkan lembar observasi guru yang diisi oleh guru kelas (observer).

\section{b. Aspek Siswa}

Lembar observasi kegiatan belajar siswa digunakan untuk mengetahui keaktifan belajar siswa dalam proses pembelajaran IPS dengan menggunakan model pembelajaran kooperatif tipe Snowball Throwing. Pada setiap pertemuan, observer mengamati dan memperhatikan belajar siswa di dalam proses pembelajaran, kemudian mengisi lembar observasi berdasarkan lembar observasi siswa yang diisi oleh guru kelas (observer)

Adapun uraiannya sebagai berikut :

\section{1) Hasil Observasi Siklus II Pertemuan II a. Aspek Guru}

Berdasarkan lembar observasi guru yang diisi oleh guru kelas (observer), dari hasil mengajar guru pada pertemuan pertama dianggap masih belum berhasil sehingga dilaksanakan kembali pada pertemuan kedua.

\section{c. Aspek Siswa}

Lembar observasi kegiatan belajar siswa digunakan untuk mengetahui keaktifan belajar siswa dalam proses pembelajaran IPS dengan menggunakan model pembelajaran kooperatif tipe Snowball Throwing. Pada setiap pertemuan, observer mengamati dan memperhatikan belajar siswa di dalam proses pembelajaran, kemudian mengisi lembar observasi berdasarkan lembar observasi siswa yang diisi oleh guru kelas (observer).

\section{d. Hasil Belajar Siswa}

Pengukuran hasil belajar siswa pada mata pelajaran IPS di kelas V SD 224 Palae Kabupaten Sinjai, diklasifikasikan yaitu: baik sekali, baik, cukup, kurang, dan sangat kurang. 
Berdasarkan hasil tes penelitian dijelaskan bahwa dari 20 subjek penelitian, terdapat 5 siswa atau $25 \%$ yang memiliki hasil belajar pada kategori baik sekali, disusul kategori baik sebanyak 50 siswa atau $40 \%$, dan kategori cukup sebanyak 5 siswa atau $25 \%$. Sesuai dengan nilai rata-rata hasil belajar siswa pada mata pelajaran IPS pada siklus kedua sebesar 79,77 dimana nilai rata-rata tersebut berada pada inteval 70,0 - 84,5 yang berarti baik. Jadi, hasil belajar murid pada mata pelajaran IPS dikelas V SDN Mappala Kota Makassar pada tes kedua dalam kategori baik, dan sudah tidak ada lagi siswa yang memiliki hasil belajar pada kategori kurang seperti pada siklus pertama. Namun terdapat $13,33 \%$ siswa yang tidak tuntashasil belajarnya sesuai standar KKM 70.

\section{e. Refleksi}

Dari segi proses pembelajaran yang telah dilakukan dengan mengacu pada hasil observasi maka dapat disimpulkan :

Siklus II pertemuan I. Untuk kegiatan guru indikator penilaiannya yakni keterlaksanaan deskriptor dan instruksi jelas dan mudah dipahami. Nilai yang didapatkan untuk kegiatan mengajar guru pada pertemuan pertama siklus II telah meningkat yakni 76,19\%. Untuk kegiatan siswa indikator penilaiannya adalah keaktifan dan keterlaksanaan deskriptor. Nilai yang didapatkan untuk kegiatan siswa pada pertemuan pertama siklus II adalah $80 \%$. Jadi rata-rata nilai yang didapatkan dari kegiatan guru dan kegiatan siswa adalah 78,09 \% telah memenuhi standar keberhasilan dari segi proses yakni jika $\geq 75 \%$ dikategorikan berhasil.

Siklus II pertemuan II. Untuk kegiatan guru indikator penilaiannya yakni keterlaksanaan deskriptor dan instruksi jelas dan mudah dipahami, Nilai yang didapatkan untuk kegiatan mengajar guru pada pertemuan ke dua siklus II adalah 85,81 \%. Sedangkan untuk kegiatan siswa indikator penilaiannya adalah keaktifan dan keterlaksanaan deskriptor. Nilai yang didapatkan untuk kegiatan siswa pada pertemuan ke dua siklus II adalah $86,67 \%$. Jadi rata-rata nilai yang didapatkan dari kegiatan guru dan kegiatan siswa adalah 86,24\% sudah memenuhi standar keberhasilan dari segi proses.

Dari segi hasil pembelajaran. Hasil tes yang didapatkan pada siklus II adalah jumlah siswa yang mendapatkan nilai $\geq 70$ terdapat 15 siswa atau 78,94 \% yang telah mendapatkan nilai $\geq 70$ dan dikategorikan lulus (tuntas), sedangkan yang belum tuntas belajar ada 4 siswa atau $21,06 \%$ atau tidak mencapai nilai $\geq$ 70. Hal ini menunjukkan bahwa pada siklus II sudah mencapai ketuntasan secara klasikal.

Dapat disimpulkan bahwa penelitian yang dilakukan pada siklus II dari segi proses (aspek guru/siswa) maupun dari segi hasil belajar sudah menuai keberhasilan. Dengan demikian maka tujuan pembelajaran yang telah ditetapkan sudah tercapai, dan tidak perlu lagi di lanjutkan ke siklus berikutnya.

\section{Pembahasan}

Hal yang akan dibahas pada bagian ini adalah penerapan model pembelajaran kooperatif tipe Snowball Throwing untuk meningkatkan hasil belajar siswa pada mata pelajaran Ilmu Pengetahuan Sosial (IPS) kelas V SDN Mappala Kota Makassar, di antaranya menggunakan model pembelajaran yang relevan dengan materi pembelajaran agar siswa dapat lebih mudah menguasai materi pelajaran berupa model pembelajaran Snowball Throwing yaitu siswa dibentuk menjadi beberapa kelompok yang diwakili ketua kelompok untuk mendapat tugas dari guru, kemudian masing-masing siswa membuat pertanyaan yang dibentuk seperti bola (kertas pertanyaan) lalu diberikan ke siswa lain yang masing-masing siswa menjawab pertanyaan dari bola yang diperoleh. Model ini siswa belajar dalam kelompok kecil yang terdiri dari 4-5 orang yang secara heterogen dan bekerjasama saling ketergantungan yang positif dan bertanggung jawab atas ketuntasan bagian materi pelajaran yang harus dipelajari dan mampu menjawab pertanyaan yang diperoleh dari tiap-tiap bola kertas dengan baik dan benar sehingga tujuan pembelajaran dapat tercapai dengan maksimal.

Hasil penelitian dengan silkus I melalui pembelajaran kooperatif tipe Snowball Trowing di kelas V SDN Mappala Kota Makassar menunjukkan bahwa hasil belajar siswa yaitu rata-rata $61,41 \%$ atau pada kategori cukup yang mencapai $47,36 \%$, tetapi terdapat pula $31,57 \%$ siswa yang memperoleh hasil belajar pada kategori kurang. Bahkan nilai hasil belajar siswa belum mencapai standar KKM yaitu 70 sebesar $57,9 \%$ atau hanya $42,10 \%$ yang tuntas belajarnya secara klasikal. Hasil observasi menunjukkan bahwa penerapan langkah-langkah model pembelajaran kooperatif tipe Snowball Trowing telah dilakukan walaupun masih ada aspek tertentu kurang maksimal, seperti ketua kelompok mendapat tugas dari guru 
menjelaskan materi yang telah dijelskan dan pada saat tanya jawab, untuk demikian halnya dengan aktivitas belajar siswa yang menunjukkan adanya sebagian siswa kurang aktif, seperti: saat ketua kelompok kembali ke kelompoknya dan menjelaskan kembali materi yang dijelaskan guru, tidak aktif bertanya jawab dengan teman atau guru.

Menanggapi hasil belajar IPS, aktivitas mengajar guru dan aktivitas belajar siswa melalui model pembelajaran kooperatif tipe Snowball Trowing pada siklus I, maka dilakukan diskusi antara peneliti dan guru kelas (obsever) sebagai upaya meningkatkan kualitas pembelajaran dan hasil belajar siswa. Hal ini dilakukan dengan cara melakukan telaah terhadap kelemahan dalam pembelajaran agar proses pembelajaran kooperatif tipe Snowball Trowing pada siklus II dapat lebih maksimal dalam mendukung peningkatan kemampuan belajar dan hasil belajar siswa.

Hasil tes penelitian pada siklus II menunjukkan bahwa hasil belajar siswa mencapai rata-rata 79,77 atau pada kategori baik sekali sebesar $40 \%$, bahkan sudah tidak ada lagi siswa yang memperoleh hasil belajar dalam kategori kurang seperti pada siklus I. Disamping nilai rata-rata hasil belajar siswa yang mencapai 79,77 sehingga lebih tinggi dari standar KKM yaitu 70, juga memenuhi ketuntasan belajar yang mencapai 86,66 \%. Demikian pula keaktifan siswa mengikuti pelajaran guru, mampu menjawab pertanyaan dari bola kertas, bertanya jawab dengan teman dan guru.

Pada siklus I terdapat 13 siswa yang memenuhi standar KKM dan terdapat 7 siswa yang belum memenuhi standar KKM. Sedangkan pada siklus II terdapat 17 siswa yang memenuhi KKM dan terdapat 3 siswa yang belum memenuhi KKM.

Hasil penelitian diatas menunjukkan adanya peningkatan hasil belajar siswa pada mata pelajaran IPS melalui model pembelajaran kooperatif tipe Snowball Throwing di kelas V SDN Mappala Kota makassar, artinya model pembelajaran kooperatif tipe Snowball Throwing sangat efektif digunakan dalam meningkatkan kemampuan belajar dan hasil belajar siswa.

Berdasarkan hasil penelitian tersebut, maka model pembelajaran kooperatif tipe Snowball Throwing mengedepankan peningkatan keaktifan siswa dalam belajar melalui permainan bola kertas yang berisi pertanyaan yang harus dijawab. Pembelajaran ini sangat efektif untuk meningkatkan keaktifan belajar siswa selama proses belajar karena siswa belajar sambil bermain sehingga siswa dapat lebih menguasai materi pembelajaran dan pada gilirannya dapat meningkatkan hasil belajar siswa SDN Mappala Kota Makassar dalam pembelajaran IPS.

Hal yang akan dibahas pada bagian ini adalah penerapan model pembelajaran kooperatif tipe Snowball Throwing untuk meningkatkan hasil belajar siswa pada mata pelajaran Ilmu Pengetahuan Sosial (IPS) kelas V SDN Mappala Kota Makassar, di antaranya menggunakan model pembelajaran yang relevan dengan materi pembelajaran agar siswa dapat lebih mudah menguasai materi pelajaran berupa model pembelajaran Snowball Throwing yaitu siswa dibentuk menjadi beberapa kelompok yang diwakili ketua kelompok untuk mendapat tugas dari guru, kemudian masing-masing siswa membuat pertanyaan yang dibentuk seperti bola (kertas pertanyaan) lalu diberikan ke siswa lain yang masing-masing siswa menjawab pertanyaan dari bola yang diperoleh. Model ini siswa belajar dalam kelompok kecil yang terdiri dari 4-5 orang yang secara heterogen dan bekerjasama saling ketergantungan yang positif dan bertanggung jawab atas ketuntasan bagian materi pelajaran yang harus dipelajari dan mampu menjawab pertanyaan yang diperoleh dari tiap-tiap bola kertas dengan baik dan benar sehingga tujuan pembelajaran dapat tercapai dengan maksimal.

Hasil penelitian dengan silkus I melalui pembelajaran kooperatif tipe Snowball Trowing di kelas V SDN Mappala Kota Makassar menunjukkan bahwa hasil belajar siswa yaitu rata-rata $61,41 \%$ atau pada kategori cukup yang mencapai $47,36 \%$, tetapi terdapat pula $31,57 \%$ siswa yang memperoleh hasil belajar pada kategori kurang. Bahkan nilai hasil belajar siswa belum mencapai standar KKM yaitu 70 sebesar $57,9 \%$ atau hanya $42,10 \%$ yang tuntas belajarnya secara klasikal. Hasil observasi menunjukkan bahwa penerapan langkah-langkah model pembelajaran kooperatif tipe Snowball Trowing telah dilakukan walaupun masih ada aspek tertentu kurang maksimal, seperti ketua kelompok mendapat tugas dari guru menjelaskan materi yang telah dijelskan dan pada saat tanya jawab, untuk demikian halnya dengan aktivitas belajar siswa yang menunjukkan adanya sebagian siswa kurang aktif, seperti: saat ketua kelompok kembali ke kelompoknya dan menjelaskan kembali materi 
yang dijelaskan guru, tidak aktif bertanya jawab dengan teman atau guru. Siswa akan semakin percaya diri dengan efektifnya penerapan model ini. (Bakhtiar;2017) belajar siswa melalui model pembelajaran kooperatif tipe Snowball Trowing pada siklus I, maka dilakukan diskusi antara peneliti dan guru kelas (obsever) sebagai upaya meningkatkan kualitas pembelajaran dan hasil belajar siswa. Hal ini dilakukan dengan cara melakukan telaah terhadap kelemahan dalam pembelajaran agar proses pembelajaran kooperatif tipe Snowball Trowing pada siklus II dapat lebih maksimal dalam mendukung peningkatan kemampuan belajar dan hasil belajar siswa.

Hasil tes penelitian pada siklus II menunjukkan bahwa hasil belajar siswa mencapai rata-rata 79,77 atau pada kategori baik sekali sebesar $40 \%$, bahkan sudah tidak ada lagi siswa yang memperoleh hasil belajar dalam kategori kurang seperti pada siklus I. Disamping nilai rata-rata hasil belajar siswa yang mencapai 79,77 sehingga lebih tinggi dari standar KKM yaitu 70, juga memenuhi ketuntasan belajar yang mencapai $86,66 \%$. Demikian pula keaktifan siswa mengikuti pelajaran guru, mampu menjawab pertanyaan dari bola kertas, bertanya jawab dengan teman dan guru.

Pada siklus I terdapat 13 siswa yang memenuhi standar KKM dan terdapat 7 siswa yang belum memenuhi standar KKM. Sedangkan pada siklus II terdapat 17 siswa yang memenuhi KKM dan terdapat 3 siswa yang belum memenuhi KKM.

Hasil penelitian diatas menunjukkan adanya peningkatan hasil belajar siswa pada mata pelajaran IPS melalui model pembelajaran kooperatif tipe Snowball Throwing di kelas V SDN Mappala Kota makassar, artinya model pembelajaran kooperatif tipe Snowball Throwing sangat efektif digunakan dalam meningkatkan kemampuan belajar dan hasil belajar siswa.

Berdasarkan hasil penelitian tersebut, maka model pembelajaran kooperatif tipe Snowball Throwing mengedepankan peningkatan keaktifan siswa dalam belajar melalui permainan bola kertas yang berisi pertanyaan yang harus dijawab. Pembelajaran ini sangat efektif untuk meningkatkan keaktifan belajar siswa selama proses belajar karena siswa belajar sambil bermain sehingga siswa dapat lebih menguasai materi pembelajaran dan pada gilirannya dapat meningkatkan hasil belajar siswa SDN Mappala Kota Makassar dalam pembelajaran IPS.

\section{SIMPULAN}

Data hasil belajar siswa pada mata pelajaran IPS setelah diberikan tindakan melalui model pembelajaran kooperatif tipe Snowball Throwing di kelas V SDN Mappala Kota Makassar menunjukkan bahwa pada siklus pertama yaitu pada kategori cukup kemudian pada siklus kedua pada kategori baik. Berdasarkan hasil penelitian tersebut maka dapat disimpulkan bahwa penerapan model pembelajaran kooperatif tipe Snowball Throwing pada mata pelajaran IPS dapat meningkatkan hasil belajar siswa kelas V SDN Mappala Kota Makassar.

\section{DAFTAR RUJUKAN}

\section{Afrizal .2014.Metode Penelitian Kualitatif.} Jakarta : PT RajaGrafindo Persada.

Aqib, Zainal. 2014. Model-Model, Media dan Strategi Pembelajaran Konstektual (Inovatif). Bandung: Yrama Widya

Arikunto, Suharsimi dkk. 2008. Penelitian Tindakan Kelas. Jakarta: PT Bumi Aksara

Bakhtiar, M. I., Saman, A., \& Aryani, F. (2017, October 7). Mengatasi Kecemasan Sosial Melalui Pendekatan Behavioral Rehearsal. Retrieved from osf.io/preprints/inarxiv/qjerf

Bakhtiar, M. I., \& Kasim, S. N. (2017, October 7). Cognitive Restructuring Application Techniques To Reduce Student Behavior In Academic Procrastination. Retrieved from osf.io/preprints/inarxiv/njgqx

Daniati, Vera. 2013. Peningkatan Hasil Belajar Siswa Dengan Model Kooperatif Tipe Snowball Throwing Pada Pembelajaran Seni Tari Kelas VIII C di SMP N 1 Bukittinggi. Jurnal Pendidikan dan Keguruan Vol. 2 (1)

Darmadi, Hamid. 2013. Metodologi Penelitian Pendidikan dan Sosial.Bandung: Alfabeta 
JIKAP PGSD: Jurnal Ilmiah Ilmu Kependidikan

Dimyati dan Mudjiono. 2009. Belajar Dan Pembelajaran. Jakarta: Rineka Cipta

Elfanany, Burhan. 2013. Penelitian Tindakan Kelas. Yogyakarta: Araska

Fathoni, Abdurarrahmat. 2011. Metodologi Penelitian dan Teknik Penyusunan Skripsi.Jakarta: Rineka Cipta

Fathurrohman, Pupuh dan Sobry Sutikno. 2007. Strategi Belajar Mengajar. Bandung: PT RefikaAditama

Huda, Miftahul. 2011. Cooperative Learning. Yogyakarta: Pustaka Pelajar

Muhadi. 2011. Penelitian Tindakan Kelas.

Yogyakarta: Shira Media

Shoimin, Aris. 2014. 68 Model Pembelajaran Inovatif dalam Kurikulum 2013. Yogyakarta: Ar-Ruzz Media

Sugiyono. 2011. Metode Penelitian Pendidikan. Bandung: Alfabeta

Undang-Undang Republik Indonesia No. 20 Tahun 2003 tentang Sistem Pendidikan Nasional. Yogjakarta: Laksana.

Yaba. 2011. Ilmu Pengetahuan Sosial (IPS) 1.

Makassar: FIP UNM

Yuni, Dewi. 2011. Penerapan Model Pembelajaran Snowball Throwing Untuk Meningkatkan Kualitas Pembelajaran IPS Pada Siswa Kelas V SDN Kalibanteng Kidul 01 Kota Semarang. Jurnal Pendidikan dan Keguruan, Vol. 1 (2) 